\title{
ASSESSING RUSSIA'S MILITARY STRATEGY IN THE EASTERN MEDITERRANEAN THROUGH THE ESTABLISHMENT OF AN A2/AD (ANTI-ACCESS/ANTI DENIAL) ZONE
}

\author{
Militia Christi Pandelaki, Anak Agung Banyu Perwita² \\ ${ }^{1}$ President Center for International Studies (PRECIS), President University; Indonesia: \\ militiapandelaki@gmail.com \\ ${ }^{2}$ Defense Diplomacy Study Program, Indonesia Defense University; Indonesia: banyu.perwita@idu.ac.id
}

\begin{abstract}
Abstrak
Studi ini menjelaskan strategi Rusia dalam melindungi kepentingan nasionalnya di Mediterania Timur dengan membentuk perluasan zona A2/AD (Anti-access/Area Denial). Artikel ini dirancang untuk menguraikan tujuan dan strategi militer Rusia dalam membangun zona A2 / AD yang berkontribusi pada perumusan kebijakan pertahanan Rusia dalam mengamankan rezim Assad. Studi ini menggunakan penelitian kualitatif dan menemukan bahwa tujuan Rusia dibagi menjadi dua. Pertama adalah tujuan jangka pendek untuk mempertahankan kekuasaan Assad. Kedua, tujuan jangka panjangnya adalah untuk mencegah pengaruh Barat dengan mengerahkan angkatan bersenjatanya yang canggih di Mediterania Timur.
\end{abstract}

Kata Kunci: Anti-access/area denial, kepentingan nasional, strategi militer.

\begin{abstract}
This study elucidates Russia's strategy in protecting its national interests in the Eastern Mediterranean by establishing an A2/AD (Anti-access/Area Denial) zone expansion. This article is designed to elaborate on Russia's military objective and strategy in establishing an A2/AD zone which contributes to the formulation of Russia's defence policy in securing the Assad regime. This study uses qualitative research and finds that Russia's goals have been divided into two folds. First is the short-term goal which is to keep Assad in power. Second, the long-term goal is to deter the influence of the Western by deploying its advanced armed forces in the Eastern Mediterranean.
\end{abstract}

Keywords: Anti-access/area denial, national interests, military strategy 


\section{Introduction}

Russia's efforts to reform its global power status started to grow rapidly when President Vladimir Putin came into power in the year of 2000. As a way to expand its wings, Russia uses the strategic location of the Eastern Mediterranean in order to fulfill its national interests which were referring to the 2000 Foreign Policy Concept of the Russian Federation, it mentioned the national interest of Russia in which is generally to ensure reliable security of the Russian Federation as well as to preserve and strengthen its sovereignty and territorial integrity to achieve prestigious positions in the world community which is mostly related to the Russian Federation as a great power (Russian Government, 2000).

With that being concerned, as one of the armed conflicts going on in the region, Russia decided to intervene the Syrian war in 2015 following to the invitation of President Bashar alAssad. Russia's support for Assad's regime has started in 2015 with its air support, weapons, and troops on the ground to counter the rebels group. Russia is also backing Syria through diplomatic way at the UN and in several international peace talks (Mason, 2017). The policy that Russia made up until this time in Syria is a form of threat perceptions towards the Western coalition (NATO and the U.S). According to the new naval doctrine of the Russian Federation, it notices the threat of the U.S. and NATO in the World Ocean that is emerging new risks to its national security (Russian Government, 2017). Therefore, if we get to review the Defense Policy of Russia in Syria ever since it starts intervening the war, both its military objectives and strategies are aimed to overthrow the coalition's throne in Syria.

Russia's military objectives in Syria are believed to be rooted from the emergence of the terrorist groups. These groups are then defined by the President of Russia as the so-called "Islamic State, Jabhat al-Nusra, and other groups that have been declared by the UNSC" (Russian Government, 2015). This is referred to the statement of President Putin that was concerning the aims of its military intervention in Syria, he generally says, "I would like to repeat that the main goal of our actions in Syria was to stop the global evil and not to let terrorism spread to Russia" (Russian Government, 2016). One year later, in 2017, Russia was taking Iran and Turkey in the joint work on Syria to prevent the disintegration of the country. The talk has been named as the Astana process, with the concern to ensure a political settlement in Syria (Russian Government, 2017). 
Based on these objectives, Russia conducted several military campaigns that were initiated to counter the mainstream opposition groups around the cities of Homs and Hama (Kainikara, 2018: 83). The campaign's disposition includes the air, naval, as well as the ground in several regions in the battlefield that is all described in the strategy of an A2/AD zone in Syria (Borschchevskaya, 2019: 21). Below is the current political map of Syria in which shows the left areas of Northeast Syria is still under control by the SDF- The Syrian Democratic Forces. A rebel group that is backed by the U.S. which is dominated by the Kurdish People's Protection Units (YPG). Aside the U.S., the group is also supported by France and other Western nations with funding, training, weapons, etc (Indelicato, 2019). Russia's forces are exploited the former U.S bases after its troops' withdrawal.

\section{SYRIA: Who controls what}

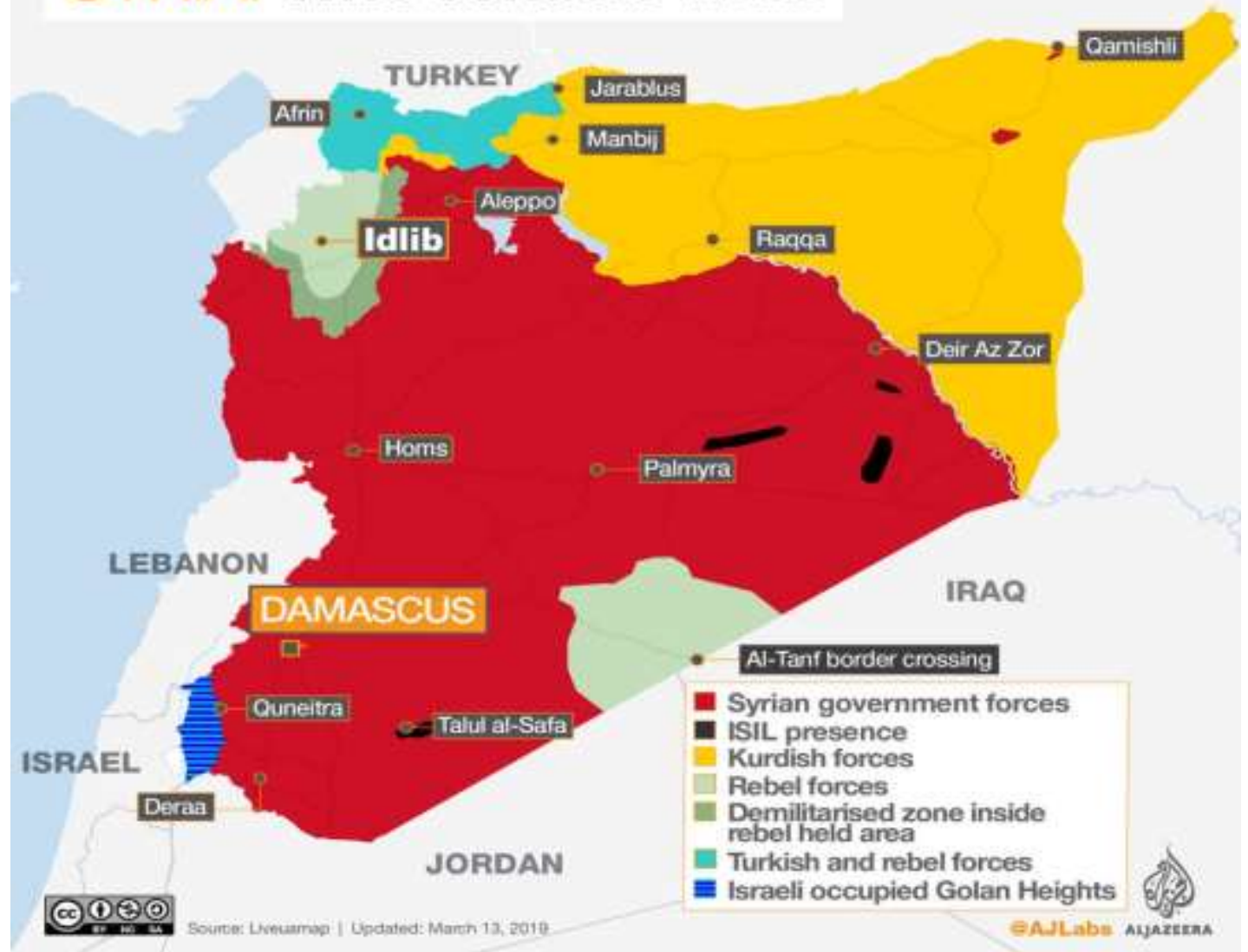

Source: https://www.nationsonline.org/gallery/Syria/Syria-war-situation-map.jpg 
According to Kofman (2020), ever since the intervention in 2015, he has summarized all the phases of military campaigns Russia had conducted in Syria (Kofman, 2020: 51). There are four phases of operations which are first, the focus to purge encroaching forces in Latakia in order to create Russia's personal buffer space. This interest is pursued with its counterpart, Turkey, to ensure the security in the Turkish-Syrian borders (Russian Government, 2019). Second, to support the Syrian army taking back the ancient city of Palmyra in 2016. However, Russia's focus in this campaign was also about the siege of Aleppo. Under the ceasefire agreements signed by the representatives of 47 inhabited areas, Russia has provided military assistance to the Aleppo City (Russian Ministry of Defense, 2017). Third, there was the second battle in Palmyra which was happened in 2017. This is to help the Syrian government to seize Deir ez-Zor from ISIS. The combat tasks against ISIS forces in Deir ez-Zor was carried out by Russian Tu-22M3 long-range bombers that covered by the Su-30Sm and Su-35S fighters (Russian Ministry of Defense, 2017). Fourth, focusing on the capture of remaining territory in Idlib. This interest has a lot to deal with Turkey as to achieve it; Russia needs to ensure Turkish support towards the FSA forces to stop (Russian Government, 2019).

Therefore, after the brief elaboration of the military objectives and strategies of the Russian Federation in Syria, the writers hope that those explained the basic and yet the most important part in the establishment of Russia's A2/AD zone in the Eastern Mediterranean. As the aim of Russia in establishing the zone in this region is to protect the Syria's regime so it is important to know specifically about the role of Russia in the war through the understanding of its military objectives and strategies. Moreover, the writers aim to further explicatethe military strategy of Russia in establishing and securing the zone through the military deployments in its naval and air bases in Syria. More specifically, these military deployments were conducted when it is facing the threat of the existence of the opposition groups which are dominated by the Western coalition. Hence, the article is then designed to explain Russia's military objective and strategy in Syria under the establishment of the A2/AD zone and to elaborate its armed forces deployment in Syria. It is also aimed to elaborate the challenges that might appear for Russia to protect its A2/AD zone which mostly about the military stance of the key actors which is one of them is Turkey. 


\section{Defense Policy and Anti-access/Area Denial (A2/AD)}

\section{Defense Policy}

The concept of defense policy can be defined as an action or conduct which intended "to influence the decisions, actions, and other matters" that is "overall relating to military affairs based on the security strategy of the nation" (Tagarev, 2006: 17). This concept covers several aspects such as ends (things to be achieved), ways and means (how and what kind of resources needed to support the ends). Defense policy is used to promote the nation's values and interests under security strategy and the involving the role of the military. This whole idea represents the definition of defense objectives which often expressed as defense missions. The formulation of defense policy is based on the state's national interest. As part of defense policy, a state needs to conduct military relations with other states for the sake of its defense policy objectives to be achieved. These relations can be in the form of bilateral, trilateral, or multilateral. Military relations can be defined as a conduct of peace missions and operations between states (Spišák, 2013: 76).

The concept of military relations cannot be separated with the strategy to the use of armed forces that encompasses several factors such as the resources, the missions, and other aspects in the environment. States have to use its military capability to attain a goal in this case is the defense policy that is overall explained the national interest of the state (Bruneau \& Croissant, 2019: 3). In the military relationship, the states have to combine military strategies to integrate their efforts which generally includes roles and missions, employment, deployment, and target priority (Perwita, 2016).

For simplicity, military relations also relate to the concept of military strategies which is then used to identify actions that is aiming to achieve the defense policy that has been made. In the concept of military strategy, for states to conduct the actions, it needs military power, such as military forces, territory, and resources to control an adversary (Albino et al., 2016: 1). The success of a strategy is depended on the capabilities of what kind of system that the states are executing. Traditionally, it includes the capability of manpower and firepower. The foundation of military strategy is usually aiming to take advantage of the enemy's vulnerability to damage their capability. Once it becomes fragile, any stress applied would likely to bring the force to destruction or defeat.

As the actualization of its national interest in the strategic environment of the Eastern Mediterranean, it is establishing an anti-access/area-denial (A2/AD) zone. As the efforts to welloperate the zone, Russia deployed its S-400 SAM systems in Syria as a key component of its 
A2/AD strategy (Boulegue \& Giles, 2019). This deployment indeed challenges the US and NATO. Therefore, in the process of maintaining this, Russia needs to ensure Turkish non-interference in the Syrian War or by at least ensuring Turkey to stop taking military action knowing that Turkey is geographically strategic as its strait is the one that allows Russia to access the region. The fact is Turkey's stance in the Syrian War is contradicted by Russia as Turkey opposes Syria's regime. By ensuring Turkey, Russia can access the Eastern Mediterranean and continue the development of the $\mathrm{A} 2 / \mathrm{AD}$ zone.

In the context of this study, Russia has been implementing several military strategies as the results of its threat perceptions towards the existence of the Western coalition in the region, specifically in Syria. It uses the coalition's vulnerability which is Turkey that has long been in a state of resentment towards the coalition. The military relations between Russia and Turkey can be seen through the joint operations along the Syrian border, and the arms trade in which Turkey has purchased the Russian S-400 system.

\section{Anti-access/Area Denial (A2/AD)}

Essentially, the concept of Anti-Access/Area Denial (A2/AD) can be defined as "an attempt to deny/prevent an adversary movement on the battlefield". It utilizes "attack aircraft, warships, and specialized ballistic and cruise missiles aimed to strike the key targets". While, Area Denial employs "more defensive means such as air and sea defense systems" (Krepinevich et al., 2003).

Figure 2 - Russian Defense Strategy Concept

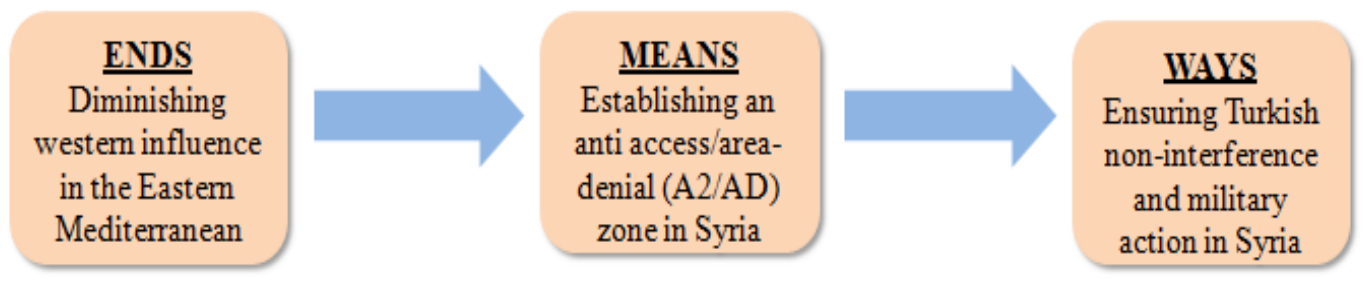

This concept provides a basis for Russia's defense policy. As the actualization of its national interest in the strategic environment of Eastern Mediterranean, it is establishing an A2/AD zone. This deployment indeed challenges the US and NATO. Therefore, in the process of maintaining this, Russia needs to ensure Turkish non-interference in the Syrian War or by at least ensuring Turkey to stop taking military action knowing that Turkey is geographically strategic as its strait 
is the one that allows Russia to access the region. The fact is Turkey's stance in the Syrian War is contradicted to Russia as Turkey opposes the Syria's regime. By ensuring Turkey, Russia is able to access the Eastern Mediterranean and continue the development of the A2/AD zone.

Moreover, reflecting to the explanation above, the case of military relationship between Russia and Turkey is included in the type of bilateral military relationship which is basically realistic towards each other. This type of alliance characteristic is usually only one side that protects the other as they have known that the allied party will not employ an independent defense policy (Tertrais, 2004). In this case, to pursue its national interest to create a multipolar system, Russia needs to ensure a balance of military action in Syria. Therefore, besides the establishment of an A2/AD zone, Russia's defense policy is also actualized with its military support towards Turkey's interest in Syria to fight against the Kurds movement through several military missions and armed forces deployment. This is to persuade NATO and the U.S that both Russia and Turkey are making progress to pursue their own interest in the conflict. Russia knows that Turkey's political affiliations in NATO would lead itself to seeking a favour from a greater power in certain cases. Therefore, one important thing to be noticed here is that this military alalliance between Russia and Turkey is considered strict reflecting to the fighter jet crisis in 2015 which resulted to Russia's economic sanctions towards Turkey once it decided to against Russia.

\section{Research Method}

To have a better understanding on the subject of this topic, this research will be using the strategy of a qualitative method. It is important to know that a research methodology is not only limited to which method that the author would likely to choose, but also how the data is collected by providing the logical reason for the chosen method. Therefore, by qualitatively conducted the research, the author is positive that it can be a lot easier to analyze and explore the data. The result of this research is then designed to be more descriptive and narrative rather than scientific report.

Moreover, the writers have collected all the relevant data from several resources. First, using primary data from the Russian Federation such as official English-translated documents, English-translated statements from the official government, and official website. Second, using secondary data that mostly from books, academic journal, and reports/news. By using these methods, it is believed that the data collected have served to decipher the main arguments of this article (Berg, 2001). 


\section{Russia's Military Components in Syria (2015-2019)}

Russia has deployed several of its armed forces in supporting Syria's regime. These forces are also deployed as the tools for Russia in pursuing its military objectives in Syria through the strategy of establishing an A2/AD zone. Russia's armed forces focused on an extensive offensive air campaign under the Russian aerospace forces (Harrington \& Katz, 2020: 20).

"The Russian army continues to play a key role in achieving peace in Syria. The Aerospace Forces group, ships and submarines of the Navy, including those deployed at the Khmeimim airbase and the naval base in Tartus, are guarantors of peace and stability in that country. Over 12,000 professionally trained officers were sent to the Army and Navy. The level of screening under contract has been also raised." (Russian Government, 2018).

In general, Russia has several amount of fleets and flotilla. Those are the Northern Fleet, Baltic Fleet, Black Sea Fleet, Caspian Flotilla, and the Mediterranean Eskadra - which is a combination of ships from the Black Sea Fleet and Northern Fleet. According to the head of the information support department of the Black Sea Fleet, Vyacheslav Trukhachev, "In the Mediterranean Sea, as part of the permanent formation of the Navy, about 15 warships and support vessels of the Black Sea Fleet are performing tasks" (Novosti, 2017). Most of these frigates and submarines armed with several Kalibr missiles that are stationed in the naval base in Tartus.

Whereas, in supporting its military campaign in Syria, Russia has arranged several Su30SM multirole fighters at the air base in Hmeimim (Kofman \& Rojansky, 2018). In 2018, Russia is believed to carry out over 34.000 combat sorties. Those combat sorties are served by the $\mathrm{Su}-24 \mathrm{~s}$ and $\mathrm{Su}-34 \mathrm{~s}$ as the primary strike aircraft (Borschevskaya, 2019: 20). Not to mention the ISR assets that are also dedicated into the theater, this includes the II-20 system, Tu-214 system, and the A50 system (p.74). All these forces are combined with the air defense assets of the Syrian military in which is based at Hmeimim.

\section{Russia's Military Deployment in Syria (2015-2019)}

The bilateral agreement between Russia and Syria in January 2017 allows Russia to enlarge its military presence in the country. The agreement includes the doubling space for Russian warships in Tartus as well as giving Russia the rights to secure an air base near Latakia, which is specifically 
located in Hmeimim. The agreement provides the access of Russia to the naval base in Tartus under a 49-year lease that could renew for a further 25 years if neither side objected (Russian Government, 2017).

Based on this agreement, Russia's military deployment in both air and naval base has increased a lot. The base at Hmeimim which becomes Russia's air station to accommodate the aviation of the Russian Aerospace Forces, it is believed that there has accommodated some 4,000 troops and capable of accepting Russian super-jumbo Antonov An-124 and Tupelov Tu-76 transport aircrafts (Russia Today, 2015). In 2019, referring to the report by the Ministry of Defense of the Russian Federation, "there are currently 20 SU fighters and MI helicopter in the airbase" (Russian Government, 2019).

Besides, Russia is also conducting an advanced deployment in its naval base in Tartus. Russia's naval deployment in Syria is dominated by the Mediterranean Squadron which had been into several orders of battle by the time Russia started its military intervention in Syria (Delanoe, 2019). However, the whole rotational basis is still under monitor by the Black Sea Fleet.

Figure 3 - Russian Naval Vessels Regular Deployment in Tartus Port, Syria

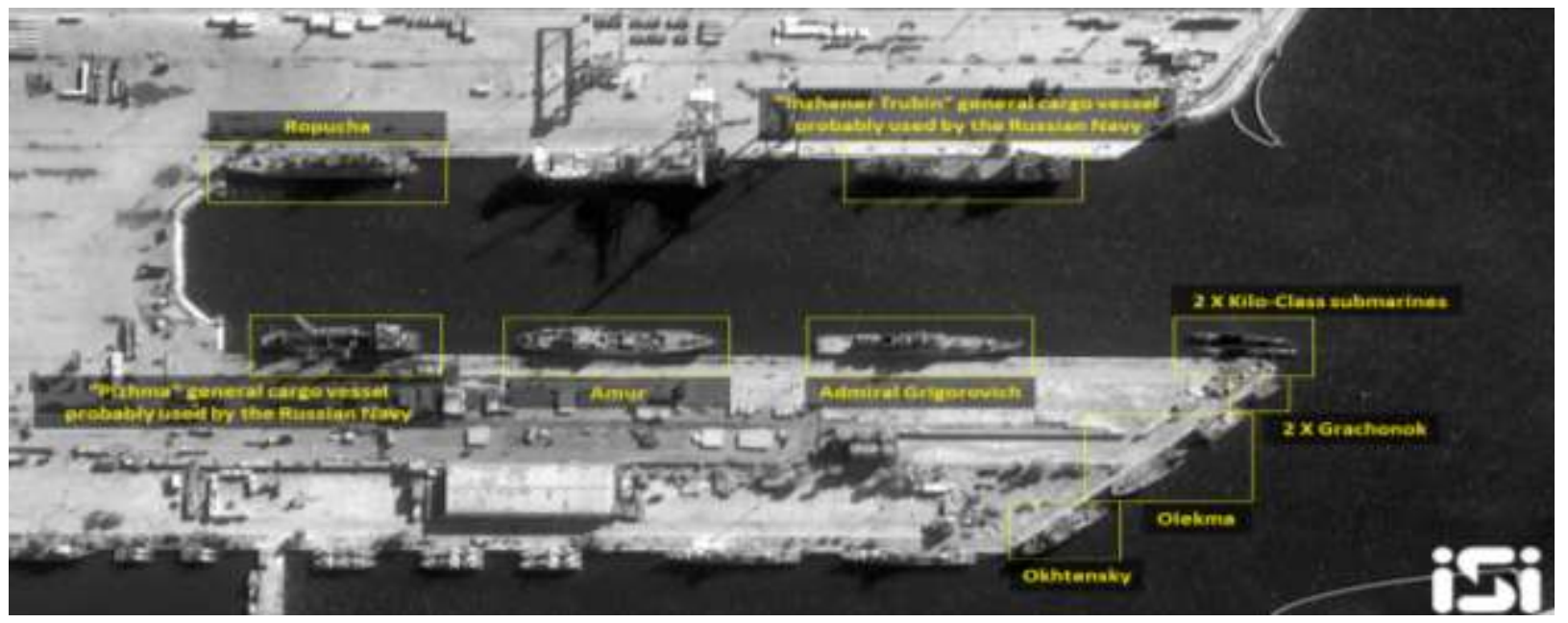

Source: https://www.globalsecurity.org/military/world/syria/tartous.htm)

Based on the figure above, in the year of 2019, several Russian submarines were patrolling in Tartus which is marked as the first Russian parade. The parade was consisted of the dieselelectric submarine Stary Oskol, the frigate Admiral Grigorovich, etc (Global Security, 2019). In 2018, the Russia's Deputy Minister of Defense of Russia, Timur Ivanov announced Russia's plan to build of a shipyard in Tartus. Under this establishment, the ministry also planned to create ground 
infrastructure (Russian Government, 2018). This is based on his statement saying, "We have a joint project for the construction of a shipbuilding workshop or a shipbuilding plant together with the Ministry of Industry and Trade directly in Tartus for the possibility of repairing ships of various classes” (Russian Government, 2018).

Russia's presence in the war is believed to help the regime regain its territories that had been taking over by the rebels. In 2016, President Putin declared his accomplishment in achieving its objectives to regain over $10.000 \mathrm{~km} 2$ territories and then announced its troops' withdrawal.

"The effective work of our military created the conditions for the start of the peace process. I believe that the task put before the defense ministry and Russian armed forces has, on the whole, been fulfilled. With the participation of the Russian military .. the Syrian armed forces and patriotic Syrian forces have been able to achieve a fundamental turnaround in the fight against international terrorism and have taken the initiative in almost all respects." (Russian Government, 2016).

However, the government decided to keep maintaining its presence in Syria even has to withdraw some troops from the battlefield. In his statement, Putin also mentioned the operation in Tartus and Hmeimim to continue operating (Russian Government, 2016). As for 2018 until 2019, the Hmeimim air base through massive application of unmanned aerial vehicles (UAVs), has been conducting several defends operations from the attacks of the terrorist groups.

\section{The establishment of Russia's A2/AD Zone in the Eastern Mediterranean (2016-2018)}

Russia's first deployment of their defense system in Syria is in November 2015, with the deployment of Russia's S-400 defense system. Based on the concept of an A2/AD bubble, it has to have an advanced air defense system in which for Russia, it has these anti-aircraft systems called S-300 and S-400 (Pinko, 2017: 35). The first official map of Russian A2/AD expansion in the Eastern Mediterranean was firstly introduced in 2016 which is believed to be the actualization of Russia's strategy in impeding the U.S and its NATO allies from establishing air supremacy in its area of interests. 
Figure 4 - The 2016 Russia's IADS in Syria

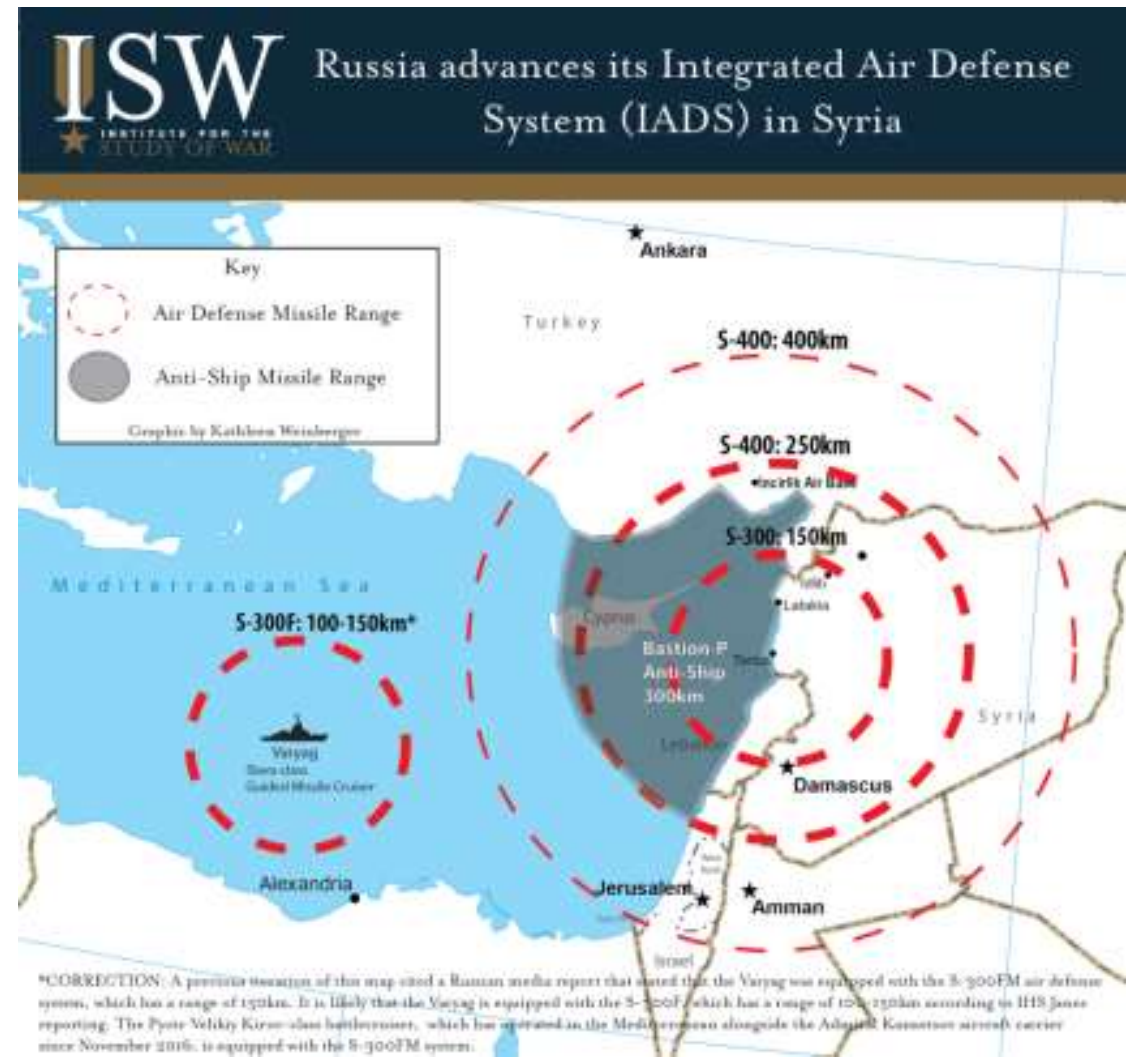

Source: http://www.iswresearch.org/2016/08/russian-anti-access-and-area-denial.html

Russia's A2/AD bubbles are not only covering its own territory, but also covered the sites in Syria. Based on the figure above, the $\mathrm{S}-400$ deployments have several ranges that are first being confirmed was around $250 \mathrm{~km}$ and the unconfirmed range was around $400 \mathrm{~km}$. These ranges fall over the Baltic States in which Turkey is included (Weinberger, 2016). The concept of an A2/AD zone relates to the role of naval and air forces, this is why the agreement to extend the lease of both of Russian naval and air bases in Tartus and in Hmeimim is important as it contributes a lot in pursuing Russia's longterm goals in the region which is to diminish the Western influence (Pinko, 2017: 36). Moscow has been trying to support Syria's air defense system with an objective to deter both Israel and the Western coalition. As for 2017, the year become the construction year for Russia to rebuild both of the bases in Tartus and in Hmeimim so that it could station more than 10 to 20 ships there. By August 2017, Russia later deployed additional SAMs which consist of three additional air defense battalions which are two units of S-400 and one unit of S-300. In 2018, Russia's A2/AD focused on the deployment of air defense systems to expand its air defense network. Under the Russian Federation Council Defense and Security Committee Chair, Viktor 
Bondarev, who served as to provide a direct respond from the Russian government regarding the prompted airstrikes, the Chair has mentioned to establish a multi-layered air defense system to protect Russia’s national security interest (Russian Government, 2018).

"The creation of the multi-layered and highly efficient air defense system in Syria capable of protecting military and civil facilities from air attacks is possible with Russia's assistance already now. The presence of highly efficient defensive weapons in the arsenal of any sovereign country will sober the hot heads of not only NATO's military and generals” (Russian Government, 2018).

In the same year, Russia has deployed three additional battalions of S-300s to Syria which is specifically two kilometers away from the occupied Russian S-400 and Syrian S-200 (TASS, 2018). As to overcome the lack direct command-and-control at the airbase in Hmeimim, Russia then deployed the Polyana-D4 with a more long-range air defense system which is covering wider area than the Barnaul-T (Cafarella \& Suomenaro, 2018). Not only that, Russia decided to provide the Syrian forces its S-300 system as it considers the old Syrian S-200 could not detect Russia's plane as a friendly one. Even though it has caused a lot of confrontation within the opposition team, which are the U.S and specifically the Israelis who were being accused on the downing (Russian Government, 2018).

Figure 5 - The 2018 Russia's A2AD systems in Syria

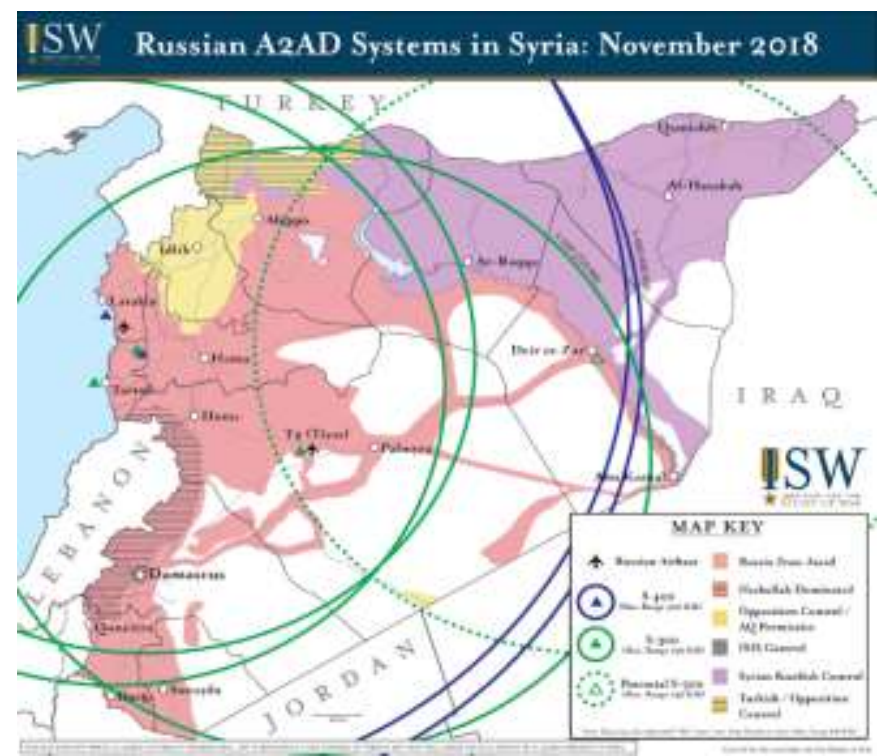

Source: http://www.iswresearch.org/2018/11/russia-expands-its-air-defense-network.html 
Based on the figure above, it is reportedly that Russia located its newly deployed battalion at the T4 (Tiyas) airbase. The figure also shows the range areas that each SAM capable to cover. With the S-400 system could cover Turkey and any other neighborhood countries for a maximum $400 \mathrm{~km}$. The S-300 system is focusing on the specific areas in Syria which are Idlib, Latakia, Tartus, Hama, Homs, Damascus, Aleppo, Palmyra, Tiyas, Al-Raqqa, and Deir Zohr (Cafarella \& Suomenaro, 2018).

Table 1 - Russian EW systems in Syria

\begin{tabular}{lll}
\hline System & Fixture & Role \\
\hline Krasukha-4 & Ground-mobile & $\begin{array}{l}\text { Protected Russian air facilities from Western intelligence } \\
\text { platforms (S-band, J-band, X-band) }\end{array}$ \\
\hline Borisoglebsk-2 & Ground & Offensive ground jammer-disrupted electromagnetic \\
& frequencies \\
\hline Vitebsk & Airborne & Created a canopy around helicopters to protect from anti-air \\
& & missiles such as MANPADS. Installed on Ka-52 attack \\
& & helicopters \\
\hline Khibiny & Airborne & Jammed the guidance systems of ground- or air-based anti-air \\
& & missiles. Installed on helicopters and aircraft
\end{tabular}

Note: The table is taken from (Jones, 2020)

Besides that, Russia also has several new electronic warfare systems in Syria. It is reportedly deployed four units of Electronic Warfare Systems (Table 2). This system used to monitor and disrupt the operations of the adversaries which in this case are the U.S and its NATO allies. In order to alert threats for the future potential attacks by the U.S, Russian Defense Minister, Sergey Shoygu stressed regarding the jam of the satellite navigation, airborne radar in the Eastern Mediterranean. This is for Russia to provide further defense activities to Syria. This is referred to the statement of Shoygu that "Russia is to supply Syria with more advanced anti-missile technology, and jam radar signals in the Eastern Mediterranean” (Russian Government, 2018).

\section{The Challenges of Russia's A2/AD Zone in the Eastern Mediterranean}

As the Russian objectives in establishing an A2/AD zone are to deter the influence of the Western coalition, the challenges that would likely to be faced by Russia are the political and military stance 
of that particular states it tries to deter. These actors are mostly dominated by the U.S and its NATO allies, which Turkey included. Their presence is important as it influence a lot in defining the next policy Russia would likely to make.

The offensive strikes from the coalition forces which are from the U.S., U.K., and France, indeed considered as a threat to the existing A2AD of Russia in Syria. One of the offensives that had been carried out was the 20182018 strike that rooted from the suspected chemical weapons attack in Douma, the former rebel stronghold (Aljazeera, 2018). Based on the statement of Nikki Haley, the US ambassador to the UN, the main interest of the U.S were to ensure the chemical weapons posed by the Syrian government were not giving any threats to the U.S interests; made sure the defeated of ISIS; and the Iran movement on the battlefield (Aljazeera, 2018). Whereas for NATO, under the chief of NATO, Jens Stoltenberg, representing all NATO allies declaring its back and support towards the Syria air strikes which carried out by the U.S., U.K, and France (Aljazeera, 2018). The chemical weapons attack by the Syrian government invited the coalitions to call on Russia and Iran to act as the main supporter of the Syrian government. However, the Russian and Iranian were on the Syrian side declaring that the attacks by those three countries are only made the conflict worsen which automatically affecting to the conflict resolution (Aljazeera, 2018).

Reflecting to this issue, it is indeed a challenge for Russia, and not to mention, all the proAssad team, to negotiate with the Western powers regarding their concern to keep the regime in Syria (Moatti \& Sheikhmohammady, 2013). This is because of the indirect intervention by the Western coalition which is more into the use of proxies is increasing with the military support such as training forces under CIA, etc. The turning point was when the U.S government decided to withdraw from Syria. Referring to the announcement by President Trump via his account on Twitter which basically declared the defeat of ISIS in 2018, the states had been squaring off its troops withdrawal which later been fulfilled in October 2019 (Blanchard et al., 2017: 26). This hastily made decision have resulted chaos within the allies. Especially to the Syrian Kurdistan (YPG) which supposed to be backed by the U.S. Now that the states have withdrew most of its forces, it brought a great advantage to Turkey in its fight against the YPG. On the other hand, Russia is then using this moment to take over the former US bases in northern Syria. After the U.S. withdrawal, the northeast region now belongs to Russia and the regime forces. 
In addition, as the changing situation requires Russia to take a further action as the only left arbiter, Turkey's military stance in Syria is indeed challenging Russia's consideration. In regards to the interest of Turkey in the war which is to prevent the YPG from entering Turkish borders by conducting several military offensives against the YPG in Northern Syria. Turkish involvement in the war is actually rooted from the Adana agreement with Syria that according to Turkey, Syria has violated the agreement by letting the YPG expand its wings even wider in Northern Syria. Ever since the crisis in Syria erupted, many scholars have reviewed that the Syrian government inclined to play the PKK card against Turkey (Rakhmatov, 2019: 173). In this situation, Russia and Turkey have stood up on the same page concerning that both countries are highly considered the Adana agreement.

"The problem of security on the Syrian-Turkish border arose chiefly due to the decision by the US to withdraw its units, its special forces and its military advisors from these areas. The situation definitely requires urgent steps to prevent a vacuum there. We consider it quite possible for Turkey and Syria to use the bilateral Adana agreement of 1998. As I understand, the Syrian government made a statement recently on the willingness to work on the basis of this agreement to provide security along the border" (Russian Government, 2019).

Pursuing this further, as a strategy in pursuing a political settlement in Syria, Russia and its counterparts - Turkey and Iran - joined a peace talk called the Astana Process. However, to relate with what Turkey demands for all this time which is regarding to the reactivation of the Adana agreement, in response to that, the Syrian regime requires Turkey to stop its support to the FSA forces that were controlling the Idlib Province. This area of Idlib is one of the main security interests of Russia in militarily intervening Syria. This is because of the existence of the Chechnya's forces which has long been into an insurgency dispute with Russia. As in for Turkey, securing the Idlib Province is important to limit the regime's territories enlargement (Katz, 2020: $55)$.

That is most likely to become the challenges for Russia in securing its interests and maintaining its A2/AD zone in Syria. As to persuade Turkey, it needs to persuade the regime too. This is because of the one who is being discussed here is the existence of the YPG. Therefore, as 
the effort to face this challenge, Russia is offering the rebel groups and the Assad regime to mediate in establishing a secure zone near the eastern Euphrates River (Russian Government, 2019).

\section{Russia's Strategy in Securing the A2/AD Zone under the Deployment of Russian Naval Fleet (2016-2019)}

Russia deploys several naval fleets to support its interest in the Eastern Mediterranean which to be specific in the Syrian war. Russia then re-established its Mediterranean squadron that has been resurrected since the beginning of 2010 and started to operate in 2013 which under the command of the Black Sea Fleet (hereinafter BLF) (Delanoe, 2019: 24). In simple words, the Mediterranean squadron consists of the Black Sea Fleet units which by the time have been reinforced by the ships from the Baltic Fleet, Northern Fleet, and the Pacific Fleet. Under its naval power presence in the Mediterranean, Russia has steadily augmented the capabilities of its squadron which includes the BLF (Blank, 2016).

In 2016, Russia has equipped its ships with an advanced sea-launched Kalibr cruise missile which was starting to be deployed sooner around the Mediterranean Sea. This is connected to its naval operations under the mission to protect Syria. The Kalibr missile system could launch at a distance up to 2,600 km. The Mediterranean Squadron has several combat operations that are also contributed by the Black Sea Fleet and the Caspian Sea Flotilla. In 2017, Russia deployed an addition of six Varshavyanka-class submarines to the BSF which then been stationed two such vessels in its naval base in Tartus (Gorenburg, 2019: 2). In 2018, the BLF contributed to the combat operations with the Mediterranean Squadron, the BSF vessels have also been actively patrolling around Syria and even involved in firing Kalibr missiles at ground targets throughout the country. The BLF were expected to carry 55 percent of these rotations. In the same year, by passing through the Turkish straits (Bosporus and Dardanelles), Russia shipped three frigate systems and one landing ship which are the Admiral Grigorovich, Admiral Essen, Pytlivy, and Nikolai Filchenkov to the Mediterranean and that is currently stationed in the port of Tartus (RFE/RL, 2018). And there is one deployment of a guided-missile corvette (FSG) named the Orekhovo-Zuyevo (Project 21631) that has started transiting the straits to join the Mediterranean Squadron (TASS, 2018).

Here, the significance of the Turkish straits can be seen clearly, as it relates to the flow of Russian naval operations in the Mediterranean. Russia needs to pass through the Turkish straits in order to redeploy and to sending reinforcements in Russian client states in the region (Gorenburg, 
2019: 6). It is a big hindrance for Russia, especially if Turkey keeps continuing to follow the strictures of the 1936 Montreux Convention regarding the regime of the Straits.

"[Article 20] In time of war, Turkey being belligerent, (...) the passage of warships shall be left entire to the discretion of the Turkish government. [Article 21] Should Turkey consider herself to be threatened with imminent danger of war she shall have the right to apply the provisions of Article 20 of the present Convention" (The Montreux Convention, 1936).

The convention generally gives Turkey a full control over its straits. In peacetime, it also guarantees the free passage for civilian vessels. The article that worries Russia more is the Article 20 and 21 which gives the right for Ankara to close the waterways whenever it is involved at war (The Montreux Convention, 1936).

\section{Conclusion}

This article concluded the formulation of Russia's defense policy which is to secure the Assad regime by assessing the military objective and strategy used by the Russian Federation in Syria. There are several crucial points that contribute in its formulation. First, to make sure that its presence has been guaranteed in a long-term period, Syria agreed to lease the bases in Tartus and Hmeimim to Russia for another 49 years. Second, the policy has to be rooted from an advanced military structure. Therefore, Russia has been deploying its armed forces which focuses on the air and naval forces that often conduct a military parade across the region. For the air forces, Russia has deployed its S-300 and S-400 systems. Whereas, the naval forces are generally under the command of the Mediterranean Squadron which consists of the Black Sea Fleet and the Northern Fleet. Third, those SAMs systems are involved in the establishment of an A2/AD zone. This deployment influenced the offensive's range as the maximum range the S-400 could cover is around $400 \mathrm{~km}$ and for the $S-300$ is around $150 \mathrm{~km}$. The important of these ranges are it could cover up until Turkey and any other neighborhood countries that includes in the area of interests of the Russian Federation.

Moreover, for Russia to protect its $\mathrm{A} 2 / \mathrm{AD}$ zone, it needs to ensure a military balance on the battlefield which requires Russia to approach several key actors which in this case is Turkey. This article proves that Turkey holds an important factor in giving access for Russia's armed forces deployment in the Eastern Mediterranean. However, as both Turkey and Syria are on bad-terms in 
regard to the Adana agreement, it portrays a big hindrance for Russia's A2/AD knowing the fact of Turkish offensives against the YPG only worsen the situation in the war.

\section{References}

Albino, D. K., Bary-yan, Y., Friedman, K., \& Glenney, W. G. (2016). Military strategy in a complex world. Research Gate , 4-17.

Aljazeera. (2018, April 15). Syria strikes: All the latest updates. Retrieved from https://www.aljazeera.com/news/2018/04/15/syria-strikes-all-the-latest-updates/

Berg, B. K. (2001). Research methodology for the social sciences (4th ed). Massachusetts: Allyn \& Bacon.

Blanchard, C. M., Humud, C. E., \& Nikitin, D. M. (2017). Armed conflict in Syria: Overview and U.S. response. Congressional Research Service, 25-27.

Blank, S. (2016, March 4). The meaning of Russia's naval deployments in the Mediterranean. Retrieved from https://jamestown.org/program/the-meaning-of-russias-naval-deploymentsin-the-mediterranean/

Borschchevskaya, A. (2019). Shifting landscape: Russia's military role in the Middle East". The Washington Institute for Near East Policy, 19-74.

Boulegue, M., \& Giles, K. (2019). Russia's A2/AD capabilities: Real and imagined. Parameters , 6-14.

Bruneau, T. C., \& Croissant, A. (2019). Civil-Military relations: Why control is not enough. Lynne Rienner, 3.

Cafarella, J., \& Suomenaro, M. (2018, November 30). Russia expands its air defense network in Syria. Retrieved from http://www.iswresearch.org/2018/11/russia-expands-its-air-defensenetwork.html

Delanoe, I. (2019). Russia's Black Sea fleet: Toward a multiregional force. CNA Occasional Paper , 24-27.

Global Security. (2019, February 22). Russian naval base at Tartus/Tartous. Retrieved from https://www.globalsecurity.org/military/world/syria/tartous.htm

Gorenburg, D. (2019). Russia's naval stratey in the Mediterranean. George C. Marshall European Center for Security Studiess, 1-6.

Harrington, N., \& Katz, B. (2020). The military campaign. In S. Jones, Moscow's war in Syria (pp. 20-23).

Jones, S. (2020). Russian goals and strategy. In S. Jones, Moscow's war in Syria (pp. 13-15).

Kainikara, S. (2018). In the bear's shadow: Russian intervention in Syria. Canberra: Air Power Development Centre.

Katz, B. (2020). The diplomatic campaign. In S. Jones, Moscow's war in Syria. 55.

Kofman, M. (2020). Syria and the Russian armed forces: An evaluation of Moscow's military strategy and operational performance. In R. Hamilton, C. Miller, \& A. Stein, Russia's war in Syria: Assessing Russian military capabilities and lesson learned (pp. 49-52).

Kofman, M., \& Rojansky, M. (2018). What kind of victory for Russia in Syria? Military Review Online Exclusive , 9-15.

Krepinevich, A., Watts, B., \& Work, R. (2003). Meeting the anti-access and area-denial challenge. Centre for Strategic and Budgetary Assessments , 4-5. 
Mason, O. (2017, March 14). Disengagement from the Syrian civil war won't come cheap for Russia. Retrieved from https://mepc.org/journal/russia-syria-unequivocal-return-middleeast

Moatti, A., \& Sheikhmohammady, M. (2013). Formal strategic analysis of the conflict over Syria. Research Gate, 1.

Novosti, R. (2017, June 1). The number of Russian navy ships in the Mediterranean increased. Retrieved from https://ria.ru/20170601/1495568751.html

Perwita, B. (2016). Defense Policy Framework. Power Point .

Pinko, E. (2017). Russian anti-access/area denial (A2/AD) in the Mediterranean arena: Implications of the Israeli navy. Haifa Research Centre for Maritime Policy \& Strategy, 3436.

Rakhmatov, D. (2019). Russia \& Turkey as strategic role players in Syrian crisis. Aralik , 172-182. RFE/RL. (2018, August 29). Russia builds up Mediterranean Fleet amid rising tensions over Syria. Retrieved from https://www.rferl.org/a/russia-builds-up-mediterranean-fleet-amidrising-tensions-over-syria-idlib-province-assad/29458959.html

Russia Today. (2015, October 3). Russian airbase in Syria: RT checks out everyday life at Latakia airfield. Retrieved from https://www.rt.com/news/317528-latakia-russian-khmeimimairbase/

Russian Government. (2019). A statement regarding a bilateral cooperation with Turkey in creating a buffer zone in Syria. Retrieved from http://en.kremlin.ru/events/president/news/59718

Russian Government. (2019). A statement regarding Russia's air defense deployment in Syria. Retrieved from http://en.kremlin.ru/events/president/news/62401

Russian Government. (2017). A statement regarding Russia's military objectives in the Astana process. Retrieved from http://en.kremlin.ru/events/president/news/56152

Russian Government. (2018). A statement regarding the establishment of Russian air defense system. Retrieved from https://tass.com/defense/1000450

Russian Government. (2019). A statement regarding the mediation between Syria's regime and the $Y P G$. Retrieved from http://en.kremlin.ru/events/president/news/62047

Russian Government. (2015). A statement regarding the troops withdrawal from Syria. Retrieved from http://en.kremlin.ru/events/president/news/51526

Russian Government. (2016). A statement regarding the troops withdrawal from Syria. Retrieved from https://www.theguardian.com/world/2016/mar/14/vladimir-putin-orders-withdrawalrussian-troops-syria

Russian Government. (2017). Fundamentals of the state policy of the Russian Federation in the field of naval operations for the period until 2030.

Russian Government. (2017). Moscow cements deal with Damascus to keep 49-year presence at Syrian naval and air bases. Retrieved from https://tass.com/defense/926348

Russian Government. (2018). Russia to jam signals in Syria and supply regime with more advanced anti-missile technology after plane was shot down. Retrieved from https://www.telegraph.co.uk/news/2018/09/24/russia-jam-signals-syria-supply-regimeadvanced-anti-missile/

Russian Government. (2019). Syrian rebels say Russia deploys ground troops in Idlib push. Retrieved from https://www.aljazeera.com/news/2019/7/18/syrian-rebels-say-russiadeploys-ground-troops-in-idlib-push

Russian Government. (2000). The foreign policy concept of the Russian Federation. 
Russian Ministry of Defense. (2017). A statement regarding Russian airstrikes against ISIS in Deir ez-Zohr. Retrieved from https://eng.mil.ru/en/news_page/country/more.htm?id=12108899@egNews

Russian Ministry of Defense. (2017). A statement regarding Russia's interest in Aleppo. Retrieved from https://eng.mil.ru/en/news_page/country/more.htm?id=12114377@egNews

Spišák, J. (2013). Military concepts - A background for future capabilities development. Research Gate , 76.

Tagarev, T. (2006). The art of shaping defense policy: Scope, components, relationships (but no algorithms). The Quarterly Journal, 17-19.

TASS. (2018, April 21). Russian navy warship transiting Black Sea straits to join Mediterranean Squadron. Retrieved from https://tass.com/defense/1147561

TASS. (2018, October 9). Three Russian S-300PM battalion sets delivered to Syria free of chargesource. Retrieved from https://tass.com/defense/1147561

Tertrais, B. (2004). The changing nature of military alliances. The Washington Quarterly, 135136.

The Montreux Convention. (1936). The Montreux Convention regarding the regime of the straits.

Weinberger, K. (2016, August 29). Russian anti-access and area denial (A2AD) range: August 2016. Retrieved from http://www.iswresearch.org/2016/08/russian-anti-access-and-areadenial.html 